\title{
Enhancing Financial Education: Debt-Taking And Charity-Giving Context In Indonesia
}

\author{
Laily Dwi Arsyianti, ${ }^{1}$ Salina Kassim, ${ }^{2}$ and Adewale Abideen Adeyemi ${ }^{3}$ \\ ${ }^{1}$ Department of Islamic Economics, Faculty of Economics and Management, \\ Bogor Agricultural University, IPB Darmaga Campus, Indonesia \\ E-mail: arsyianti@apps.ipb.ac.id \\ 2Institute of Islamic Banking and Finance, International Islamic University \\ Malaysia, UIA Gombak Campus, Malaysia \\ E-mail:ksalina@iium.edu.my \\ ${ }^{3}$ Institute of Islamic Banking and Finance, International Islamic University \\ Malaysia, UIA Gombak Campus, Malaysia \\ E-mail: abidewale@iium.edu.my
}

\begin{abstract}
The low-income households are perceived to have the right to take debt from excessfinanced group or entitled for some charity. However, this perception has blur their attitude towards charity-giving. Low-income should not consider themselves as 'the taker' in perpetual. They should instil giving behaviour and consider themselves as 'the giver'. Experts from financial education and Islamic finance areas are interviewed. Results from Analytic Network Process suggest that setting specific targeted behaviour is the most priority, with debt-taking focus of interest. Women apparently become the most urgent targeted audience of Islamic finance education. Before executing education program, participant's belief towards Islamic value should be built. Experts suggest formal education institution be the most preferable place to establish the program, in collaboration with formal financial institutions to conduct the training and support from government budget. Introducing Islamic economics and finance values from the earlier stage of formal education would be suitable for future consideration.
\end{abstract}

Keywords: Islamic finance education, ANP, social marketing, Islamic social finance

\begin{abstract}
Abstrak
Rumahtangga berpenghasilan rendah dianggap memiliki hak berutang dari kelompok yang memiliki penghasilan berlebih atau dari beberapa badan amal. Namun, persepsi ini telah mengaburkan sikap mereka terhadap pemberian infak. Penghasilan rendah seharusnya tidak menganggap diri mereka sebagai 'penerima' selama seumur hidupnya. Mereka harus menanamkan perilaku dan menganggap diri mereka sebagai 'pemberi'. Para ahli dari pendidikan keuangan dan perencanaan keuangan Islam telah diwawancarai. Hasil dari Analytic Network Process menunjukkan bahwa penargetan mensetting perilaku khusus dalam pendidikan keuangan adalah hal yang terpenting, terutama pendidikan dalam hal pengambilan utang. Segmen wanita menjadi audiens sasaran pendidikan keuangan Islam yang paling mendesak berdasarkan para ahli. Sebelum melaksanakan program pendidikan, pengenalan peserta terhadap nilai-nilai Islam harus dibangun. Para ahli menyarankan lembaga pendidikan formal menjadi tempat yang paling cocok untuk membangun program, bekerja sama dengan lembaga keuangan formal untuk melakukan pelatihan dan dukungan dari anggaran pemerintah. Memperkenalkan nilai-
\end{abstract}


nilai ekonomi dan keuangan Islam pada tahap awal pendidikan formal sangat cocok untuk pertimbangan di masa yang akan datang.

Keywords: Pendidikan keuangan Islam, ANP, pemasaran sosial, keuangan sosial Islam

\section{INTRODUCTION}

Financial literacy has been proven to be a predictor in financial behaviour (Cole, Sampson, \& Zia, 2009). To get better literacy, one should have knowledge which could be achieved from education. However, to begin with, education expenditure in Indonesia is the lowest in the world (UNESCO, 2011).

Bank Indonesia (BI) launched a blueprint in financial education in 2007 which attempted to achieve goals in building bank-minded and awareness, building people's understanding on banking services and the rights and obligations of customers, building risk awareness in financial transactions, disseminating information about problem solving with banks including complaints and dispute-resolution (Bank Indonesia, 2011; Tambunan, 2015; Wibowo, 2013; Samosir, 2013). It has different target at different time. The blueprint targeted students, children, and youth in 2011; by 2012, it started targeting migrant workers; in 2013 and later, the programme targeted fishermen, civil society and communities in remote areas; in 2014, financial education was offered to cooperatives and micro, small and medium enterprises; and late 2015, the programme targeted factory workers. Leaflets, booklets, brochures and comics on the topics of banking institutions, savings and investments, loans, banking services, customer complaints and mediations, and the like were distributed since 2008. They were disseminated to schools, markets, housing complexes, and office buildings. The campaign of "Let's Go to the Bank" was conducted in 2008 in collaboration with all commercial and rural banks in the contrary.
Bank Indonesia also collaborated with the Ministry of Education and Culture, and Indonesian Consumer Organisation in 2008, and the Ministry of Manpower and Transmigration in 2011. In 2009, savings campaign started. TabunganKu (My Savings) advertisement was launched from 2010 onwards in Jakarta and 41 other big cities in Indonesia.

Even though the programme emphasized on savings since the beginning, the outcome of financial inclusion for savings accounts in 2015 reached only around 22\% of total adult low-income population (World Bank, 2015). Furthermore, only slightly more than $11 \%$ of that population borrowed from financial institutions. Those who did not borrow were mostly because they were not credit-worthy. More than 40\% of those who borrowed dealt with informal financial institutions.

Household financial fragility, such as not credit-worthy, related to riskier financial position when they were taking any debt from financial institutions (Rinaldi \& Sanchis-Arellano, 2006). Moreover, households' arrears were proven to have correlation with prevailing belief and the level of religiousity (Georgarakos \& Fürth, 2015). The above findings show the need for financial education in both financial fragility issue as well as religiousity that support financial behaviour.

This paper is designed to answer research question: What is the most recommended strategies to educate lowincome households in their financial behaviours? Financial education is keen to make every single group in the society to be better literate, especially in this case, in 
managing their debt-taking and charitygiving behaviours. In order to convey the message effectively, financial education programmes should be well-planned and well-structured (Giesler \& Veresiu, 2014) when the agenda can also be internalized at the governmental level. One of the methods is through social marketing as proposed by Lee and Miller (2012). However, at this stage, to contribute a fruitful recommendation, this research attempts to propose some priorities in setting strategies to educate low-income society in Indonesia.

\section{LITERATURE REVIEW}

Financial education can be a highly effective method to improve financial literacy among the society (Hogarth et al., 2003). Financial literacy is basically the possession of basic knowledge about how to earn or make financial resource, manage it to prepare for various unexpected future events, and disburse it to help others (Giesler \& Veresiu, 2014). It is also important to know how to properly utilise it according to budget constraints. Financial education is a piece of puzzle to achieve well-literacy in finance among consumers. Hogarth (2006) mentions that disclosure and information, substantive protections, and professional advice are some pieces to complete the puzzle. This is because, being well-literate in finance includes for being knowledgeable, educated and informed regarding managing money and assets, which comprise planning, implementing, and evaluating the financial decisions (Mccormick, 2009).

Through improved financial literacy, one is hoped to be better able in using the resources, increasing economic security, improving contributions to the community, and finally building a thriving community and well-educated labour force (Hogarth, 2006). This is simply because there is a correlation between knowledge and behaviour where those who are equipped with better financial education and knowledge are more likely to undertake recommended financial behaviour (M. A. Hilgert \& Hogarth, 2003).

Financial education, therefore, needs to be properly identified and targeted. In accordance with priority target, the youth seem to be the appropriate group as early in their lives, financial education would enable youngsters to observe financial discipline (Mccormick, 2009). However, there are studies which found that high-school students who took personal financial management course were no more literate than those who did not take it (Mandell \& Klein, 2009).

First time homebuyers can also become the target group (Hogarth, 2006). Buying a house is categorized as a longterm goal (Hilgert \& Hogarth, 2003; Hogarth et al., 2003). Thus, it is considered as an investment in financial behaviour. First time homebuyers may benefit from some relevant information. They should be aware of this transfer of knowledge or they will miss the opportunity while they have waited for this buying a house moment for the first time. It has been proven that receiving counselling before buying a house would lower delinquency rate (Hogarth et al., 2003). However, lowincome households are more interested to spend money for their net-worth rather than for such a long-term investment.

Another targeted group is the lowincome households. Financial education is proven to improve financial knowledge (Zhan, Anderson, \& Scott, 2006; Muflihani, 2015; Martin, 2007), improve skills (Muflihani, 2015), and change financial behaviour effectively (Lyons, Chang, \& Scherpf, 2006) particularly among the low-income populations in many countries. This group is considered to have a low financial literacy rate as their involvement in financial inclusion is still low. 
Women are also a targeted group for financial literacy (Hogarth, 2006; Kendall \& Klapper, 2015). Among developing countries, it is Indonesian women who are the highest account holders compared to its men (Kendall $\&$ Klapper, 2015). However, Yumna and Clarke (2009) suggest that instead of women, especially married women, it should be families who become a targeted group. Obaidullah (2008) states that Muslim societies are dominated by males, when the targeted group is women, the money would end up with the males while the female members in the family would carry the financial risk.

Other possible targeted groups are pre-retirees and employees. These two groups are relatively easier to be set up from their workplace. Financial education in the workplace has been proven to be effectively increasing the employees' welfare (Garman, Kim, Kratzer, Brunson, \& Joo, 1999). A comprehensive programme is needed to improve the employees' financial well-being. Most programmes are dedicated to prepare them for their retirement. The outcome is to get higher perception rate on their satisfaction in current financial situation. More confidence in making financial decision after taking the financial education at the workplace is one of indicators to assess their financial wellbeing.

\section{Social Marketing}

In influencing positive financial behaviour, Lee and Miller (2012) proposed social marketing as the method that can be used by social organisations to promote specific behaviour. They presented seven strategies as the best practices in several countries. First, the purpose and focus should be agreed upon. A behaviour change programme should set a specific mission within a specific period and should be determined in advance. For instance, an amil institution set a financial training programme to empower all mustahik, be familiar with Islamic financial transactions and transform at least half of them into muzakki within two years period. This goal is then being the guidance for amil institution to focus on setting the financial education for mustahik.

Second, the target audience should be identified and described. Who is the appropriate audience for the programme? Is it appropriate for young audience or should it be appropriate for the retiree instead? On the other hand, a question like "what is the appropriate financial education programme for working mothers?" may appear because the audience is ready to join a financial education programme but the programme has not been settled yet. Such questions should be answered meticulously. Recommended strategy should have been examined for particular situation: targeting particular audience for a programme that has already been settled, or setting a programme for particular audience who demand for financial education.

Third, specific behaviour should be selected. Another strategy is aiming a specific behaviour that should be achieved by audience after joining financial education programme. For example, a financial education organisation targeted the audience to be more aware and discipline in paying debt because nonperforming financing rate is increased in particular area. Thus, the most recommended strategy for financial education, in this particular issue, is setting a specific targeted behaviour.

Fourth, audience barriers are understood and addressed. In promoting Islamic financial products and services, the Islamic financial institutions incur the fact that their customers consider their products are similar with conventional counterpart. This issue should be 
identified and later being addressed in financial education. Thus, such financial education strategy is recommended in targeting customers for Islamic financial institutions.

Fifth, the programme should consider 4Ps (product, price, place, promotion). When a programme has been planned but a financial education organizer face difficulties in executing the idea, considering 4Ps may be the most recommended strategy in its programme for specific audience.

Sixth, partnership should be formed. Some financial education programmes may have been settled and well-planned. However, the programmes need to be executed by appropriate partners. For example, who will be appropriate in educating people to give charity more regularly? Or who will educate people in choosing the most appropriate financial product for particular transaction? Strategy of choosing the appropriate partners should be recommended for such situation.

Lastly, evaluation should be conducted and reported. When outcomes mostly fail to be achieved, financial educator should be more aware in evaluating the programme. In this sense, being more responsive on programme evaluation may be the most recommended strategy.

These strategies are not necessarily in an order from the first to the last. Instead, executing financial education should consider all circumstances in order to choose the most recommended strategy. Every condition has its own issue and may be different from one area to another area, one country to another country, or one institution to another institution. Therefore, financial education should be planned based on the most appropriate strategy in particular condition.

Three out of nine points of recommendation on principles of good practices for financial education and awareness have mentioned the role of financial institutions, which are namely good governance, human resources, and clients to support financial education programmes. Financial institutions, at the very beginning of their commencement, aim to earn as much profit as possible. Even the MFIs charge higher rate of return than commercial financial institutions (Yumna \& Clarke, 2009). They argue that they need high operational costs to cover their daily activities. Furthermore, the society, particularly Muslim population, has been offered a solution from Islamic financial institutions to choose financial products and services that comply with Islamic teachings. However, it seems that they fail to attract this segment of society. In fact, Islamic financial institutions charge higher than their conventional counterpart as the operational and overhead costs are higher relatively compared to the portion of their market share (Beik \& Arsyianti, 2008). Thus, the idea of Islamic financial institutions to narrow the wide gap between the rich and the poor in Indonesia may seem impossible. Cost is still an issue in the effectiveness of financial education (Willis, 2011).

\section{METHODOLOGY}

Experts give their opinion through a questionnaire. Experts consist of educators from state and private institutions. They include "ulama or public figures who are concerned about financial education, practitioners who are actively involved in educating people on financial issues as well as financial planners who are actively promoting financial education in daily activities, nationally and internationally. They judge based on their perception and compare between two or more indicated strategies. Their comparisons are quantified and denoted by 1 to 9 , which is not necessarily in order. 
1 is for equally importance and 9 is for extreme importance of one strategy to another. Therefore, Analytic Network Process (ANP) is the best method to achieve the objective of this study.

Analytic Network Process (ANP) is the generalized version of Analytic Hierarchy Process (AHP) (Saaty, 2008). It measures relatively the absolute scale of pairwise comparison, knowledge, and judgement of experts. Those judgements can be combined to achieve a single outcome. ANP is used when there are dependence relationships among elements in the hierarchy, unlike AHP that not have that kind of dependence relationships. ANP represents networks rather than hierarchy, therefore, its relationship can be in the form like cobweb.

Tradeoff judgements are usually made in qualitative terms. In this method, it is expressed numerically to exhibit reciprocal pairwise comparisons that are designed in a scientific way (Saaty, 2008). Eigenvector of matrix is made from judgements which are first verbally given and corresponded in the scale associated with judgement. Reciprocal judgements are used for inverse comparisons, $\left(\mathrm{C}_{\mathrm{a}}, \mathrm{C}_{\mathrm{b}}\right)$ $=1 /\left(C_{b}, C_{a}\right)$. By using $W_{i j}$ as the weight of relationship between components, equations used in ANP will be as follows, based on Saaty (2005), Ma'arif and Tanjung (2003), and Firdaus et al. (2013).

Consistency is also assessed. Inconsistency should be more than $10 \%$. Inconsistency itself is important to gain new knowledge regarding the change of preference. As judgement presented numerically, fundamental scale is used in pairwise judgement.

Table 1. Fundamental Scale

\begin{tabular}{|l|l|}
\hline Scale & \multicolumn{1}{|c|}{ Judgements } \\
\hline 1 & Equal importance \\
\hline 3 & $\begin{array}{l}\text { Moderate importance of one } \\
\text { over another }\end{array}$ \\
\hline
\end{tabular}

\begin{tabular}{|l|l|}
\hline 5 & $\begin{array}{l}\text { Strong or essential } \\
\text { importance }\end{array}$ \\
\hline 7 & $\begin{array}{l}\text { Very strong or demonstrated } \\
\text { importance }\end{array}$ \\
\hline 9 & Extreme importance \\
\hline $\begin{array}{l}2,4,6, \\
8\end{array}$ & Intermediate values \\
\hline
\end{tabular}

Source: Saaty (2008)

Super Decisions software is used to help in running the analysis and calculations, besides Excel 2010 is utilised to rank experts' decisions by using geomean. Geomean is the nth root of decisions of $n$ numbers, or denoted as:

$$
\left(\prod_{i=1}^{n} x_{i}\right)^{\frac{1}{n}}=\sqrt[n]{x_{1} x_{2} \ldots x_{n}}(1)
$$

Geomean is kind of average or mean. It is useful to calculate mean when the $x$ es have different range of data, for example $x_{1}$ has a range of 1 to 10 and $x_{2}$ has a range of 1 to 100. It normalises the range. Even though experts are allowed to answer between 1 to 9 , they not necessarily decide all in 1 to 9 range. Some indicator may only have range 4 to 6 , some may have 1 to 9 . The range may differ among indicators. Therefore, geomean is more appropriate in calculating the average of experts' decisions.

The researcher should set a specific objective before forming a structure (Saaty, 2008). Lee and Miller (2012) presents the social marketing strategy which comprises seven strategies. The strategies consist of focus in the purpose of programme, targeting the audience, changing in behaviour, overcoming the barriers, setting marketing mix, collaborating with the veracious partners, and evaluating through some assessments. Experts should assess and determine which strategy should be prioritised in the case of Indonesia.

The first strategy is focused on the purpose of the programme. In this case, the focus is to improve knowledge in debt-taking and charity giving. Second, 
the target audiences of the programme are low-income households, youngsters, firsttime home buyers, pre-retirees and employees, and women.

Third, specific behavior should be selected. In terms of debt-taking behavior, audience is targeted to be less, or at least they can fully repay before taking another debt, or, in terms of charity-giving behaviour, they will give charity at whatever amount regularly. Fourth, audience barriers are understood and addressed. Personal knowledge, belief (debt-taking is considered as the last alternative source of fund, debtor must have a will to repay all debts, the amount of debt must be at debtor's capacity, charity-giving can empower the society, and the donors/audience may benefit from it here in dunya and hereafter), skill (hard skill, such as calculating financial ratios, managing funds), and ability to perform the behavior (soft skill, such as feel grateful to what they have, do not give up easily) are addressed as possible barriers.

Fifth, the programme should consider the 4Ps (product, price, place, promotion). The products are financial education programmes: counselling (private consultation), seminar, training, formal education. The expenditure (price) is defined as financial education budget which can be taken from social or philanthropic institutions (BAZNAS and LAZ) or government institutions (Ministries: Finance, Religious Affairs, Health, Education; Bank Indonesia; OJK). The programme are expected to be placed in the social or philanthropic institutions, government institutions, or education institutions. Promotion media are expected to be newspapers, television, radio, flyers, mobile phones, and online. Sixth, partnership should be formed. The programme is expected to be conducted by social or philanthropic institutions, government institutions, formal education institutions (schools, universities, and colleges) or financial institutions (banks, insurance companies, and investment managers).

Seventh, evaluation should be conducted and assessed. It is expected that targeted audiences can calculate their debt capacity; know the cause of overindebted is using one debt to pay off another, set money aside to repay their debt, or set aside some money for charity.

Finally, ANP framework is designed by using Super Decision. Figure 4.3 shows the ANP framework of financial education based on experts.

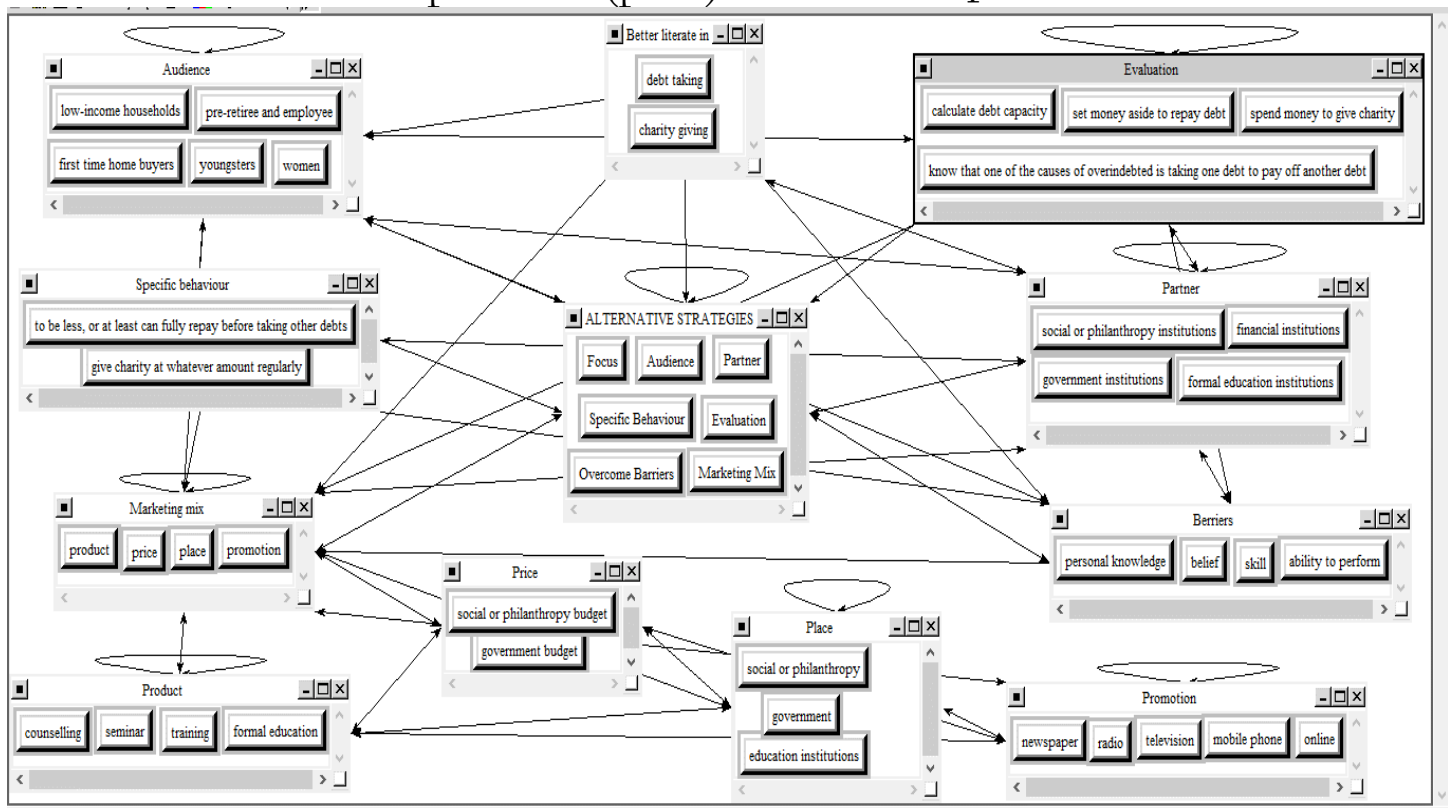

Figure 1. ANP Framework of Financial Education 
Five experts in financial education have been surveyed. They were asked through a self-administered questionnaire as attached in the appendix of this research. There are 12 clusters, in total. The cluster of alternative strategies represents the ultimate goal that should be taken into account in setting financial education. Alternative strategies include (1) focus of strategy, which is better literate in debt-taking and charity-giving; (2) audience; (3) specific targeted behaviour; (4) overcome barries; (5) marketing mix, which are product, price, place, and promotion; (6) partner who will execute financial education programme; and (7) self-financial evaluation of audience. Overall, experts' opinions are not in concordance as the Kendall's W value is 0.04 which indicates that each expert has his/her own decision.

\section{RESULTS AND DISCUSSIONS}

Data analysis shows that experts are in concordance in putting the specific targeted behaviour strategy as the top priority in setting financial education of low-income households in Indonesia. It implies that it is necessary to set which target behaviour in the stipulated financial education. Giesler and Veresiu (2014) propose that financial literacy should start with the process of personalisation, especially in the case of financial debt. It would have internalized their capability in managing their financial resources. The majority of the respondents have consecutive debt, yet give charity regularly. Arsyianti, Kassim, and Adeyemi (2017) found that financial education can shape their behaviour in taking debt consecutively to be more controlled. To the extent of control, their financial life will be more manageable. When dealing with debt, they will consider the debt within their capability to repay, they will be more eager to repay in full before taking another debt and they will consider debt as the last resort of financial source. Nevertheless, lowincome households find that they still need external resource to fulfil their family needs.

A study done by Mandell and Klein (2009) covers financial education which emphasise on specific targeted behaviour. They find that the programme was not effective in changing the behaviour of students who participated in the course. In this study, data analysis priorities the alternative strategies in setting financial education programme as shown in the following table.

Table 3 Alternative Strategy Priority Ranking

\begin{tabular}{|l|l|c|l|}
\hline \multicolumn{1}{|c|}{ Strategies } & \multicolumn{2}{|c|}{ Geomean } & Rangking \\
\hline Audience & 0.158175 & 3 & \\
\hline Evaluation & 0.12101 & 5 & \\
\hline Focus & 0.160461 & 2 & \\
\hline $\begin{array}{l}\text { Marketing } \\
\text { Mix }\end{array}$ & 0.118046 & 7 & \\
\hline $\begin{array}{l}\text { Overcome } \\
\text { Barriers }\end{array}$ & 0.150318 & 4 & \\
\hline Partner & 0.119759 & 6 & \\
\hline $\begin{array}{l}\text { Specific } \\
\text { Behaviour }\end{array}$ & 0.167654 & 1 & \\
\hline
\end{tabular}

The above table shows us that Specific Behaviour is ranked in the first position. It is followed by Focus, which is basically slightly different from Specific Behaviour. Focus is prone to encourage respondents to be better literate in debttaking and charity-giving. As mentioned by some researches (Zhan, Anderson, \& Scott, 2006; Lusardi, 2008; Cole, Sampson, \& Zia, 2009) who find that when the financial education goal is to improve financial literacy and financial knowledge, participants would improve their literacy and they find it to be an effective way.

The third priority in setting financial education strategies is to set 
who our audience. A research finds that setting the targeted audience preposition would prevent any fallacy in guiding the participants and should whether it be spread out to not only the participants (Lyons et al., 2006). Another study finds that targeted audience of financial education should be examined further whether they, for example youngsters, can receive such information (Chen, 1998; Mandell \& Klein, 2009).

To overcome barriers is apparently positioned as the fourth priority. It is in the middle of all ranks, which shows that it can be put into top priority or less priority. The barriers need to be observed whether they can be eliminated or overlooked (Lusardi, 2008). For financial education to influence effectively, initial knowledge, belief, and skills are some of the barriers that need to be examined (Lee \& Miller, 2012).

Emphasising on evaluating participants is the fifth priority. It is bit peculiar that evaluation on participants' ability and capability comes after overcoming the barriers strategy. Hence, barriers are assumed present at this stage, even though evaluation follows subsequently. Another perspective may look at this as an evaluation after the programme. Nevertheless, both process are substantial in conducting financial education (Mandell \& Klein, 2009; Chen, 1998; Lee \& Miller, 2012).

Choosing partner who can conduct financial education is the second last priority. At the social marketing point of view, (Wymer, 2011) suggests that social marketer is at the frontline who understands the situation of the target group. However, in this research, experts are in conclusion that determining the financial education promoter is not that necessary compared to other strategies.

The least important priority is marketing mix, which is quite surprising since the concept embarks from marketing field. Experts do not consider marketing mix, in this context, to be at the priority level. Instead, it is put at the last one. Yet, Kotler and Zaltman (1971) still consider marketing mix (product, price, place, and promotion) as key success of social campaign which touches target group's core value and belief.

\section{Specific Targeted Behaviour}

The first priority that should be considered in setting a financial education programme. The financial educators should acknowledge what kind of outcome behaviour they wish to see in audience. In this research, the specific targeted behaviours are giving charity regularly at whatever amount and to fully repay current debt before dealing with another debt. Here is the result from the data analysis.

The result shows that experts prefer to place more attention on fully repaying debt before taking other debts. At least the audience will take less debt, if they cannot fully repay the current debt. They are aware of the presence of this issue. Even though, it lacks of data, the World Bank has reported that only around 21\% of adult Indonesians have access to formal financial institution. It indicates the financial inclusion rate is still low compared to other nations in South-East Asia. The rest are accused of having access to informal financial resources.

Households with lower ability to cover their expenses are vulnerable economically and get access in taking credit consecutively and easily during economic hardship (Baek \& DeVaney, 2010). Respondents in this research show that they are in economic hardship. They are by unemployed, living under less than USD80 per month, with more than four members in their households. Thus, this specific behaviour should be paid attention to. As financial knowledge can improve financial behaviour (Lusardi, 2008) through financial education, emphasising on the programme on 
improving behaviour on taking debt is needed.

Furthermore, behaviour on giving charity regularly at whatever amount should not be ignored as well. Financial education is hoped to not disregard this kind of outcome from audiences, including low-income households. Even though they have relatively low income compared to other groups in society, lowincome households are encouraged to contribute to society through the spirit of sharing as well.

Encouraging

low-income households to give charity sounds strange in common society. This behaviour is dominated by wealthy donors. However, Schervish, O'Herlihy and Havens (2002) report that donors are bound in connection. They call it community of participants, who have a unique social capital called networking. Hence, it is not necessarily done by people of certain income. Donors can be bound because of, for instance, their religious community. Low-income households, to some extent, are also involved in such regular religious gathering. This moment can be used as their means to spread the spirit of sharing.

\section{Targeted Audience}

First time home buyers are the potential targeted audience in financial education since a house is a major investment and asset portfolio of most households (Hogarth, 2002). Since mortgage lending practices are common, first time home buyers should be prudent when entering a new contract. Even though unethical and fraudulent contracts are found in some cases, based on investigation, some of the terms revealed are not technically illegal but rather disadvantageous to some costumers (Braunstein, Welch, \& Affairs, 2002). For instance, youngsters who have the potential to increase future income may find paying a floating rate to be fine as they may refinance in the future. The case is not the same for those who highly depend on fixed income. Customers should be aware of this issue. Furthermore, financial education can help first time home buyers as an impetus in changing their budget behaviour as well (Shelton \& Hill, 1995).

Experts in this study, however, put this type of audience to be the least to achieve financial education in Indonesia. They find it is more urgent for other groups of audience to be educated. They relate it to the current issue in Indonesia, which indicates that home ownership is not an essential in the current situation. Based on Indonesia Banking Statistics published by Bank Indonesia (2015), housing loan for all terrace, apartment, and shop houses is relatively at a flat $9 \%$ of total loan distributed through formal institutions, from 2012 to 2015, except in April and May 2014 which was 10\%. If we compare it with other countries, especially in South-East Asia region, that figure is still lower (Badev, Beck, Vado, \& Walley, 2014). We can see, as well, this study found $72.2 \%$ of respondents have already owned their own home.

Youngsters possibility of falling into bankruptcy is high, according to Lusardi, Mitchell, and Curto (2009). Young people carry the burden of debt and hinder their ability to accumulate wealth due to this entanglement. The urgently of financial education, thus, should fall onto this group of audience. However, experts find it not necessary in the case of Indonesian young people, except two experts who consider this group audience as the second priority. Actually, young Indonesians share a substantial portion of aggregate earnings predominantly those of aged 20 and below in 1996 (Lee, Lee \& Mason, 2004), who now will be 40 years old and below. The number is higher than in France and in the US. Yet, only two of the experts gave this group more priority than pre-retirees and employees, lowincome households, and women. 
The third priority is the group consisting pre-retirees and employees. Hathaway and Khatiwada (2008) reported researches have been done in several workplaces. Employees receive financial education at their workplace about, mainly, retirement planning, especially those who are in pre-retirement period. Meanwhile, Loke and Hageman (2013) study on financial education stipulates on social workers and find it is significant to educate them about financial matter. No one among the experts in this study put this targeted group to either the least nor the top priority for financial education programme. This group in Indonesia is basically a potential participant in financial education, particularly in providing knowledge about retirement planning because their knowledge is lower than the Indians in the case of retirement savings and insurance (Cole et al., 2009). Furthermore, Hogarth (2002) found that many households do not know how much money they need during retirement.

Low-income households group is eventually the second priority among all targeted audiences. Experts consider this group to have a low rate in financial literacy. Thus, they need to be educated on financial manners. The financial consultant representative found this group to be educated intensively and directly. Lyons et al. (2006) found that even though low-income population has received financial education, their overall financial position does not shift. Therefore, they suggest revising the measurement indicator to financial decision-making skills that are more suitable in such circumstances. Eventually, they show an improvement. Zhan et al. (2006) also focus on changing financial skills on decision-making and helping low-income individuals to access financial information and opportunities.
Financial experience in Lyons et al.'s (2006) study, however, is found to be more effective than several lessons. Some lessons also establish larger marginal effects than other types of lessons, for example comparing shopping and talking with family about money. Others which are related to behaviour on financial situation are less ready to be changed after the programme. In this study, we can see that $77 \%$ of the respondents have not received any kind of financial education.

Women are the top and foremost audiences that should be prioritised in financial education programme in Indonesia. Three experts are of the same conclusion that they must be put at the top. One of them, an academician and a consultant in microfinance institution, argues that women are more reliable than men. One institution has tried to involve men into their programme, but the programme failed. Prior to this, the programme ran well under women's management. The expert argues that because of this, women's skills need further improvement, especially because of their role in households. Similar to this expert's argument, other two experts also emphasised on women's role in the households, which is like the financial minister of a household. Indonesia Financial Inclusion Agenda has also included women as the targeted audience. In order to set an effective programme, women need to be put as the top priority. Hung, Yoong, and Brown (2012) and Vonderlack and Schreiner (2002) are among researchers who promote women's need for financial education and juxtapose financial services with women, especially in low-income societies who are familiar with informal services.

\section{Overcome Barriers}

Belief is considered as the top barrier that has to be overcome. To the extent of this study, financial education participants are encouraged to deepen 
their full understanding on what they believe, especially for Muslims. The spirit of Islam is intended to be implemented not only by Muslims but also by all human beings. Muslims, as the agents of Islam, thus, should show what the true spirit in Islam is. For instance, in terms of taking debt, one should understand that debt is allowed in Islam; yet, it should be managed and controlled in a good manner. Participants of a financial education programme should know where they stand. According to Ajzen and Fishbein (1969), belief influences behaviour through attitude. Participants of a financial education should be assessed whether their belief would prevent them from achieving the outcomes, which can change their financial behaviour. Hira (1997) argues that belief can be transmitted at the early age, thus participants may already have initial belief regarding debt-taking and charitygiving. For instance, participants may believe that charity should be given later after all other needs are fulfiled, including after paying debt. In Islam, charity should be given in any situation, regardless the economic hardship.

The next top priority is ability to perform, as we can see from the following table. Ability to perform is actually participants' soft skill in executing what has been received in financial education. Before joining the programme, participants should be examined whether they have the capability to, for instance, make decisions regarding which product can minimise their financial risk. Or, in a simple manner, according to Lyons et al. (2006), comparing products during shopping which is more practicable compared to other skills.

Skill is the third to be prioritized in setting a financial education programme, in the context of overcoming barriers. It represents hard skills that participants already have. Skills need to be tested whether they would prevent them or enhance their performance towards specific financial behaviour. The skills prominently can be acquired from formal education or certified training providing financial education. In this study, respondents have neither had high education nor receive any financial education. Therefore, it is a call for practitioners to overcome this barrier in order to execute specific targeted behaviour.

Personal knowledge is the least barrier to be overcome according to experts in this study. Even though knowledge in financial matter is one of the requirements to be better in financial literacy (M. A. Hilgert \& Hogarth, 2003), experts found personal knowledge is not a top priority. Experts argued that this knowledge can be received not only from well-managed financial education programmes, but also from other means.

\section{MARKETING MIX}

Marketing mix is the least strategy to be prioritised in setting financial education programmes. Promotion is placed as the priority among marketing mix nodes. According to the experts, promoting financial education is crucial in marketing mix. The following table shows the ranking of marketing mix priority. Shifting method from face-to-face to direct means is now trending in the marketing world (Lee, 2002). Phone, mail, and e-mail are some of the means used as medium of promotion. However, two experts argued that, in Indonesia, face-toface, mouth-to-mouth, or below the line methods are more effective if marketing deals with low-income groups. Those practitioners found it from their experience in educating low-income households in microfinancing issues.

The second priority is retained by product. Product relates to methods in conveying information in financial education. Seminar, training, and workshop are some of the methods used. 
For participants to be more knowledgeable, a seminar would be appropriate. Spreading information about sukuk to university students in Indonesia is done through seminar. Hathaway and Khatiwada (2008) show that a seminar would gather more participants. It is due to its purpose in delivering information, to prepare, or to make people become aware of particular issues like what has been studied by Caldwell and Siwatu (2003).

Price, or in this context budget of financial education, is placed as third priority. Budget set by either social or philanthropy institution, or government institution is examined. Though it is not the least priority, price is eventually not crucial in setting the programme, according to experts in this study.

The least priority is place. It does not matter where the programme will take place, as long as the programme is executed. Place is the least consideration in setting the programme whether in education institution, social or philanthropy institution, or government institution.

\section{Promotion}

Online, television and mobile phone are the top three ranking on promotion. Indonesian Internet users are increasing over time (Knoema, 2016). It reaches 17.1 users per 100 people in 2014. Its growth is higher than mobile subscribers, even though mobile phone has more users (125.4 users per 100 people). This data show that online promotion is more likely to be effective than mobile phone as suggested by experts. Television unit is still highly in use, amounting to 60.2 sets of television and 0.2 cable subscribers per 1000 people (pressreference.com, 2016). In fact, respondents in this research are very familiar with television. Almost all respondents include television into their asset category. Promoting financial education through these mediums of information is more likely to be acceptable by Indonesian people.

A study done by Bernheim and Garrett (2003) shows that paper based promotion is common among employees in the workplace. Indonesian subscribers for newspapers reach 36 and 59 circulations per 1000 for daily and nondaily, respectively (pressreference, 2016). However, experts were in conclusion that the newspaper is not on the top priority list of promotion. Only one of them stated that newspaper is the first priority, the rest put it on the second least.

The least promotion is through radio. Although its receiver is the highest among all mediums, which is 137.9 per 1000 , radio is considered as the least effective promotion according to experts in this study. One expert argued that radio is not for talks, it is mainly for entertainment.

Furthermore, experts added that for low-income households, another recommended medium is through "under the line" education, which is face-to-face, mouth-to-mouth, either individually or in groups. They have this kind of social capital that motivates their financial behaviour.

\section{Product}

Training is placed as the top priority of product in financial education. Training is more practical compared to other products stipulated in this research. Fox et al. (2005), Hathaway and Khatiwada (2008), Lyons et al. 2006, and Zhan et al. (2006) are some of the studies concerning training in financial education. Training allows participants to gain knowledge as well as skills in performing what have been given in financial education.

Formal education is still hoped to be effective media in financial education programmes. However, it should start earlier than high school stage as suggested by Mandell and Klein (2009). Thus, it is 
not only taught to university student at the relevant department but also to younger student in order to shape their belief towards financial behaviour (Hira \&e Mugenda, 1999).

Seminar is effective for delivering particular information or sounding information regarding specific financial products. However, it is not a top priority according to experts in this study. Corresponding with barriers to be overcome, personal knowledge is put on the least priority.

Counselling or face-to-face on an individual basis is not necessary at the top list of priority. However, one expert argued that if that counselling is on group basis that would be more suitable for lowincome households. Indonesian people love to gather in their neighbourhood, either through religious gatherings or arisan.

\section{Price}

Budgeting financial education programme is necessary for the Indonesia government, according to experts in this study. The government should encourage this programme and spend more money to make it successful. Meanwhile, social or philanthropy budget is only complementary to embolden the programme. Social or philanthropy institutions can support financial education for certain segments of society, low-income group to be precise.

\section{REFERENCES}

(OECD). (2006, July). The Importance of Financial Education. Policy Brief, (July). http://doi.org/10.1177/002214 6515584605

(OECD). (2013). Addressing women's needs for financial education.
Place

This node is the least priority among all nodes stipulated in this study. Though formal education institution is put as the least priority of partner executing financial education, experts saw this institution as the top priority of place in conducting financial education. Government institution is placed as the second priority and social or philanthropy institution as the least. It is true that the government should support financial education programmes, but government institution is not the place where financial education should be conducted.

\section{CONCLUSIONS}

Experts indicated that financial education should be conducted in formal education institution with government budget. Financial institution should take bigger role in executing financial education and it can be done by collaborating with formal education institution. Since financial education attempts to change behaviour of lowincome group, instilling the belief is necessary and it should be done at an earlier stage like from school age.

Youngsters, however, are not a top priority targeted for financial education programmes. It is women that should be prioritised and low-income households is placed second. In conclusion, specific targeted behaviour of debt-taking is placed at the top priority among other strategies in setting financial education for low-income households.

International Network for Financial Education

Ajzen, I., \& Fishbein, M. (1969). The prediction of behavioral intentions in a choice situation. Journal of Experimental Social Psychology, 5(4), 400-416. http://doi.org/10.1016 /0022-1031(69) 90033-X 
Badan Amil Zakat Nasional. (2015). Peerimaan dan Penyaluran Tahun 2015, Bulan Juni 2015. Jakarta. Retrieved from http://pusat.baznas.go.id/wpcontent/uploads/downloads/2015/0 8/Laporan Keuangan Bulanan Baznas Juni 2015.pdf

Badev, A., Beck, T., Vado, L., \& Walley, S. (2014). Housing Finance Across Countries (Policy Research Working Paper No. 6756). Retrieved from http://documents.worldbank.org/cu rated/en/697351468165251669/Housi ng-finance-across-countries-newdata-and-analysis

Baek, E., \& DeVaney, S. a. (2010). How do families manage their economic hardship? Family Relations, 59(4), 358-368. http://doi.org/10.11ll/j.17413729.2010.00608.x

Bank Indonesia. (2008). Enam Pilar API. In Arsitktur Perbankan Indonesia (pp. 6-7). Bank Indonesia. Retrieved from

http://www.bi.go.id/id/publikasi/pe rbankan-dan-

stabilitas/arsitektur/Documents/838 faflb782a4679bdd70fdlf5bldbd4ena m_pilar.pdf

Beik, I. S., \& Arsyianti, L. D. (2008). Why the rate of financing in Islamic Banks is High? An Analysis Based on Malaysia Case. Jurnal Islamic Finance and Business TAZKIA, 3(1), 18-29. Retrieved from http://tifbrtazkia.org/index.php/TIFBR/article/ view/19

Bernheim, B. D., \& Garrett, D. M. (2003). The effects of financial education in the workplace evidence from a survey of households.pdf. Journal of Public Economics, 87, 1487-1519.
BI. (2011). Financial Inclusion: Using Financial Education to Reach Out to Undeserved Groups and the Informal Sector. In Conference on Financial Literacy: Financial education For All (pp. 1-31).

Braunstein, S., Welch, C., \& Affairs, C. (2002). Financial Literacy $\square$ : An Overview of Practice, Research, and Policy. Federal Reserve Bulletin, l(November), 445-457.

Chen, H. (1998). An analysis of personal financial literacy among college students. Financial Services Review, 7(2), 107-128. http://doi.org/10.1016/S10570810(99)80006-7

Cole, S., Sampson, T., \& Zia, B. (2009). Financial Literacy , Financial Decisions, and the Demand for Financial Services $\square$ : Evidence from India and Indonesia. Harvard Business School Working Paper 09117. Retrieved from http://wwwl.worldbank.org/prem/p overty/ie/dime_papers/1107.pdf

Disney, R., \& Gathergood, J. (2011). Financial Literaacay and Indebtedness: New Evidence for UK Consumers. The University of Nottingham., (April), 0-38.

Fox, J., Bartholomae, S., \& Lee, J. (2005). Building the case for financial education. Journal of Consumer Affairs, 39(1), 195-214. http://doi.org/10.11l1/j.17456606.2005.00009.x

Garman, E. T., Kim, J., Kratzer, C. Y., Brunson, B. H., \& Joo, S. (1999). Workplace Financial Education Improves Personal Financial Wellness. Association for Financial 
Counseling and Planning Education, (904), 79-88.

Georgarakos, D., \& Fürth, S. (2015). Household repayment behavior: The role of social capital and institutional, political, and religious beliefs. European Journal of Political Economy, 37, 249-265. http://doi.org/10.1016/j.ejpoleco.2014 .10 .001

Giesler, M., \& Veresiu, E. (2014). Creating the Responsible Consumer: Moralistic Governance Regimes and Consumer Subjectivity. Journal of Consumer Research, 41(3), 840-857. http://doi.org/10.1086/677842

Hathaway, I., \& Khatiwada, S. (2008). Do financial education programs work? (No. 803). Retrieved from http://papers.ssrn.com/sol3/papers.c fm?abstract_id=1118485

Hilgert, M. A., \& Hogarth, J. M. (2003). Household Financial Management: The Connection between Knowledge and Behavior. Federal Reserve Bulletin, 1(July), 309-322.

Hilgert, M. a, \& Hogarth, J. M. (2003). Household Financial Management: The Connection between Knowledge and Behavior. Federal Reserve Bulletin, 106(July), 309322.

Hira, T., \& Mugenda, O. (1999). The relationships between self-worth and financial beliefs, behavior, and satisfaction. Journal of Family and Consumer Sciences, 91(4), 76-82. Retrieved from http://scholar.google.com.scihub.org/scholar?q=Hira+and+Mugen $\mathrm{da}+\left(1999 \& \& b \operatorname{btn} \mathrm{G}=\& \mathrm{hl}=\mathrm{en} \& \mathrm{as} \_\mathrm{sdt}=0\right.$, $5 \notin 0$
Hogarth, J. M. (2002). Financial literary and family \& consumer scences. Journal of Family and Consumer Sciences, 94(1), 14.

Hogarth, J. M. (2006). Financial Education \& Economic Development. Retrieved from http://search.oecd.org/daf/fin/financ ial-education/37723380.pdf

Hogarth, J. M., Beverly, S. G., \& Hilgert, M. (2003). Patterns of Financial Behaviors $\square$ : Implications for Community Educators and Policy Makers. Federal Reserve System Community Affairs Research Conference, 1-28.

Hudon, M. (2009). Should access to credit be a right? Journal of Business Ethics, 84(1), 17-28. http://doi.org/10.1007/s10551-0089670-y

Hung, A., Yoong, J., \& Brown, E. (2012). Empowering Women Through Financial Awareness and Education. OECD Working Papers on Finance, Insurance and Private Pensions, (14). http://doi.org/10.1787/5k9d5v6kh56 g-en

Kobrin, F. E. (1976). The fall in household size and the rise of the primary individual in the United States. Demography, 13(1), 127-138. http://doi.org/10.2307/2060425

Kotler, P., \& Zaltman, G. (1971). Social marketing: an approach to planned social change. Journal of Marketing, 35(3), 3-12. http://doi.org/Retrieved from EBSCO HOST

Lee, J. (2002). A key to marketing financial services: the right mix of products, services, channels and customers. Journal of Services 
Marketing, 16(3), 238-258. http://doi.org/10.1108/088760402104 27227

Lee, N. R., \& Miller, M. (2012). Influencing positive financial behaviors: the social marketing solution. Journal of Social Marketing, 2(1), 70-86. http://doi.org/10.1108/2042676121120 3265

Loke, V., \& Hageman, S. A. (2013). Debt Literacy and Social Work. Journal of Financial Therapy, 4(1). http://doi.org/10.4148/jft.v4il.1795

Lusardi, A. (2008). Household saving behavior: the role financial literacy, information and financial education programs. Working Paper. Retrieved from http://www.nber.org/papers/wl382 4

Lusardi, A., \& Tufano, P. (2009). Debt Literacy, Financial Experiences and Overindebtedness (March 2009 No. 14808). Cambridge. Retrieved from http://www.nber.org/papers/wl480 8.pdf

Lyons, A. C., Chang, Y., \& Scherpf, E. M. (2006). Translating Financial Education into Behavior Change for Low-Income Populations. Journal of Financial Counseling and Planning, 17(2), 27-45. Retrieved from http://papers.ssrn.com/sol3/papers.c fm?abstract_id=2232122

Mandell, L., \& Klein, L. S. (2009). The Impact of Financial Literacy Education on Subsequent Financial Behavior. Journal of Financial Counseling and Planning, 20(206), 15-24. Retrieved from http://www.eric.ed.gov/ERICWebP ortal/contentdelivery/servlet/ERICS ervlet?accno=EJ859556
Martin, M. (2007). A literature review on the effectiveness of financial education. Federal Reserve Bank of Richmond Working Paper No 0703, June 15, 2007.

Mccormick, M. H. (2009). The Effectiveness of Youth Financial Education $\square$ : A Review of the Literature. Journal of Financial Counseling and Planning, 20, 70-84.

Muflihani, Z. F. (2015). Faktor - Faktor Yang Memengaruhi Tingkat Literasi Perbankan Syariah Pada Pelaku Usaha Mikro Di Kota Bogor. Bogor Agricultural University.

Niemira, M. P., \& Saaty, T. L. (2004). An Analytic Network Process model for financial-crisis forecasting. International Journal of Forecasting, 20(4), 573-587. http://doi.org/10.1016/j.ijforecast.200 3.09.013

Obaidullah, M. (2008). Introduction to Islamic Microfinance. New Delhi: IBF Net (P) Limited. http://doi.org/10.1355/SJ23-1D

Rinaldi, L., \& Sanchis-Arellano, A. (2006). Household Debt Sustainability: What Explains Household NonPerforming Loans? (ECB Working Paper Series No. 570). Retrieved from http://ssrn.com/abstract_id=872528

Samosir, R. E. (2013). Financial Education: Indonesia Perspective.

Schervish, P. G., O'Herlihy, M. A., \& Havens, J. J. (2002). Charitable giving: How much, by whom, to what, and how? (W. Powell \& R. Steinberg, Eds.). Yale Press. Retrieved from http://scholar.google.com/scholar?hl $=$ en\& $\&$ btnG=Search\&q=intitle:Charit 
able+Giving: + How + Much,+ By + Wh $\mathrm{om},+\mathrm{To}+$ What, + and + How? $\# 0$

Shelton, G. G., \& Hill, O. L. (1995). FirstTime Homebuyers Programs as an Impetus for Change in Budget Behavior. Journal of Financial Counseling and Planning, 6(706), 83-91. Retrieved from http://search.proquest.com.proxy.li brary.cornell.edu/docview/13647578 53?pqorigsite $=$ summon $\% 5 \mathrm{Cnhttp}: / /$ media.proquest.com.proxy.library.c ornell.edu/media/pq/classic/doc/298 $781234 \mathrm{l} / \mathrm{fmt} / \mathrm{pi} / \mathrm{rep} / \mathrm{NONE} ? \mathrm{hl}=\&$ \& cit $\% 3$ Aauth $=$ Shelton $\% 2 \mathrm{C}+$ Gladys $+\mathrm{G} \%$ 3BHill\%2C+Octavia+L\&ecit $\% 3$ Ati

Tambunan, T. (2015). Financial Inclusion, Financial Education, and Financial Regulation: A Story from Indonesia (June 2015 No. 535). Tokyo. Retrieved from http://www.adb.org /sites/default/files/publication/16117 6/adbi-wp535.pdf

UNESCO. (2011). Global Education Digest 2011: Comparing Education Statistics Across the World. Development. Montreal, Quebec: UNESCO Institute of Statistics. http://doi.org/978-92-9189-062-0

Vonderlack, R. M., \& Schreiner, M. (2002). Women, microfinance, and savings: Lessons and proposals. Development in Practice, 12(5), 602-612. http://doi.org/10.1080/ 0961452022000017614

Wibowo, P. P. (2013). Financial education for financial inclusion: indonesia perspective. Retrieved from http://responsiblefinance.worldban k.org/ /media/giawb/fl/documents/ misc/finlitedu-org-rtf/overalltf/india_1-1-3_wibowo.pdf

Willis, L. E. (2011). The Financial Education Fallacy. The American
Economic Review, 101(3), 429-434. http://doi.org/10.1257/aer.101.3.429

Wymer, W. (2011). Developing more effective social marketing strategies. Journal of Social Marketing, 1(1), 1731.

http://doi.org/10.1108/2042676111110 4400

Yayasan Dompet Dhuafa Republika. (2013). Financial Statements for the year ended December 31, 2013 with Independent Auditors' Report. Retrieved from http://www.dompetdhuafa.org/abo ut/laporan

Yulianti, M. (2013). Penerapan Metode Analytic Network Procces (ANP) Dan Technique For Order Preference By Similarity To Idel Solution (TOPSIS) Dalam Pemilihan Supplier (pp. 14-29). Bandung: Universitas Pendidikan Indonesia, repository.upi.edu, perpustakaan. upi.edu. Retrieved from repository.upi.edu/2941/6/S_MTK_0 901986_CHAPTER3.pdf

Yumna, A., \& Clarke, M. (2009). Integrating zakat and Islamic charities with microfinance initiative in the purpose of poverty alleviation in Indonesia. In 8th International Conference on Islamic Economics and Finance (pp. 1-18). Doha, Qatar.

Zhan, M., Anderson, S. G., \& Scott, J. (2006). Financial knowledge of the low-income population $\square$ : Effects of a financial education program. Journal of Sociology and Social Welfare, 33(1), 53-74. Retrieved from

http://cat.inist.fr/?aModele $=$ afficheN \&ecpsidt $=17704936$ 